Open Access

\title{
Impact of off-farm activities on technical efficiency: evidence from maize producers of eastern Ethiopia
}

\author{
Musa Hasen Ahmed ${ }^{*}$ and Kumilachew Alamerie Melesse
}

\author{
* Correspondence: musahasen@ \\ gmail.com \\ School of Agricultural Economics \\ and Agribusiness, College of \\ Agriculture and Environmental \\ Sciences, Haramaya University, P. O. \\ Box 95, Dire Dawa, Ethiopia
}

\begin{abstract}
This article analyzes the impact of participation in off-farm activities on technical efficiency of maize production in eastern Ethiopia. We combined propensity score matching with a stochastic production frontier model that corrects sample selection bias resulting from unobserved factors that potentially affect both households' decision to participate in off-farm activities and technical efficiency scores that most previous studies do not account for. The probit model results indicate that sex of the household head, literacy of the spouse, agricultural cooperative membership, family size, and access to market information had significant effect on farmers' participation in off-farm activities. In the meantime, it was found that farmers who participated in off-farm activities have a significant technical efficiency gain compared with their non-participant counterparts.
\end{abstract}

Keywords: Off-farm, Technical efficiency, Stochastic frontiers, PSM, Selection bias

\section{Background}

The vast majority of poor households living in the developing areas rely on agriculture for their food, income, and livelihood (Minten and Barrett 2008; Dethier and Effenberger 2012; Larsen and Lilleør 2014). Hence, the growth and development of the agriculture sector is considered to be the main pathway out of poverty and food insecurity and to have a pro-poor economic development in those areas (Diao et al. 2010; Kassie et al. 2013; Collier and Dercon 2014; Dawson et al. 2016).

The agriculture sector is the mainstay of the Ethiopian economy as it accounts for nearly $45 \%$ of GDP and employs about $85 \%$ of labor forces (Dercon et al. 2012). Despite its strategic role for the country's economy, the sector is dominated by subsistence and semi-subsistence farming system (Alemu et al. 2006; Anley et al. 2007; Francesconi and Heerink 2011; Teshome et al. 2016). Smallholders own on average less than 1 ha land per holder account for about $95 \%$ of land covered by crops on which they produce about $90 \%$ of agricultural outputs in the country (CSA, 2014). Moreover, the ever-increasing population of the country is reducing the farm sizes rapidly (Bezu and Holden 2014; Headey et al. 2014). This population growth coupled with a legal restriction on agricultural land market hindered farm expansion that made farms smaller and hiring labor superfluous, which created a significant level of unemployment in the rural part of the country (Bezu and Holden 2014). Hence, there has to be a mechanism

(c) The Author(s). 2018 Open Access This article is distributed under the terms of the Creative Commons Attribution 4.0 International License (http://creativecommons.org/licenses/by/4.0/), which permits unrestricted use, distribution, and reproduction in any medium, provided you give appropriate credit to the original author(s) and the source, provide a link to the Creative Commons license, and indicate if changes were made. 
to support the livelihood of the agricultural communities and absorb the excess labor in the rural economy. As emphasized by Lanjouw and Lanjouw (2001), the main options available for the unemployed rural community in this scenario are either migration to urban areas or engagement in off-farm activities in rural areas. Actually, smallholder farmers in developing countries rarely rely on a full-time agricultural work; rather, they often maintain a portfolio of activities in which off-farm activities are an important contributions to their well-being (Barrett et al. 2001; Foster and Rosenzweig 2004; Smith et al. 2005; Wouterse and Taylor 2008; Lanjouw and Murgai 2009; Zezza et al. 2009; Davis et al. 2010; Haggblade et al. 2010).

Empirical findings consistently show that incomes generated from off-farm activities ease the burden on agriculture as it enables households to have better incomes. Hence, they enhance food security as they manage food consumption fluctuations better than a household without such an activity (de Janvry and Sadoulet 2001; Ruben 2001; Barrett et al. 2001; Babatunde and Qaim 2010; Haggblade et al. 2010; Owusu et al. 2011; Bezu et al. 2012; Hoang et al. 2014; Mishra et al. 2015). Especially when the agricultural production fails due to climate change, pest, deceases, or other shocks, off-farm employment provides a risk management tool to reduce the income variability and will fill the gap that will be created between farm income and household consumption El-Osta et al (2008). By engaging in off-farm employment, farmers also become self-insured (Alasia et al. 2009) and they may invest in a risky but high-returning agricultural business.

Off-farm income can also enhance agricultural production by relaxing liquidity and credit constraints to purchase productivity enhancing agricultural technologies such as improved seed, fertilizer, machineries, and hiring labor (Ruben 2001; Lamb 2003; Matshe and Young 2004; Kilic et al. 2009; Oseni and Winter 2009; Anriquez and Daidone 2010). This is particularly true in developing countries where farmers are facing credit constraints (Stampini and Davis 2009).

Though there are ample empirical evidences on the impact of off-farm income on adoption of productivity-enhancing agricultural inputs, its impact on farm efficiency is mixed. For example, Mochebelele and Winter-Nelson (2000), Tijani (2006), Haji (2007), Pfeiffer et al. (2009), Bojnec and Ferto (2013), and Babatunde (2013) found a positive significant impact of off-farm income on farm efficiency. There are also cases (such as Goodwin and Mishra (2004), Chang and Wen (2011), and Kilic et al. (2009)) in which participation in off-farm activities has an adverse effect on the agriculture. They argued that if the income from the off-farm activities is more attractive than the agriculture, farmers might give less attention for the agriculture and they might devote more family labor and time for off-farm activities. There are also studies (such as Chavas et al. 2005, Bozoğlu and Ceyhan 2007; Lien et al. 2010, Feng et al. 2010; Chang and Wen 2011) that found no significant association between the two variables. Table 1 summarizes some of the empirical works that examined the role of off-farm activities on technical efficiency.

As it can be observed from Table 1, the findings are not consistent. This disagreement between empirical results could be due to the fact that the role of off-farm activities on farm productivity is different from context to context. The other important thing learnt from the above empirical works is that selectivity bias is not addressed in most of the cases; therefore, the reported impact and associated technical efficiency (TE) scores are likely to be biased (Bravo-Ureta et al. 2012; González-Flores et al. 
Table 1 Summary of the studies which examined the relationship between off-farm income and technical efficiency

\begin{tabular}{|c|c|c|c|c|}
\hline Authors & Country & Type of crop & Estimation technique & $\begin{array}{l}\text { Relationship between } \\
\text { TE and off-farm activities }\end{array}$ \\
\hline Tijani 2006 & Nigeria & Rice & SFA & + \\
\hline Haji 2007 & Ethiopia & Vegetable & DEA & + \\
\hline Pfeiffer et al. 2009 & Mexico & Agriculture & $\begin{array}{l}\text { Combined SFA with } \\
\text { instrumental variable }\end{array}$ & + \\
\hline Kilic et al. 2009 & Albania & Agriculture & $\begin{array}{l}\text { Combined instrumental } \\
\text { variables, Tobit, and SFA }\end{array}$ & $\begin{array}{l}\text { No systematic } \\
\text { relationship }\end{array}$ \\
\hline $\begin{array}{l}\text { Bozoğlu and } \\
\text { Ceyhan } 2007\end{array}$ & Turkey & Vegetable & SFA & $\begin{array}{l}\text { No systematic } \\
\text { relationship }\end{array}$ \\
\hline Lien et al. 2010 & Norway & Agriculture & SFA & $\begin{array}{l}\text { No systematic } \\
\text { relationship }\end{array}$ \\
\hline Feng et al. 2010 & China & Rice & Instrumental variable & $\begin{array}{l}\text { No systematic } \\
\text { relationship }\end{array}$ \\
\hline $\begin{array}{l}\text { Bojnec and } \\
\text { Fertó } 2013\end{array}$ & Slovenia & Agriculture & SFA & + \\
\hline $\begin{array}{l}\text { Chang and } \\
\text { Wen } 2011\end{array}$ & Taiwan & Rice & SFA & - \\
\hline Lien et al. 2010 & Norwegian & Grain & SFA & $\begin{array}{l}\text { No systematic } \\
\text { relationship }\end{array}$ \\
\hline Yang et al. 2016 & China & Agriculture & SFA & $\begin{array}{l}\text { No systematic } \\
\text { relationship }\end{array}$ \\
\hline Zhang et al. 2016 & China & Agriculture & $\begin{array}{l}\text { Combined SFA with } \\
\text { instrumental variable }\end{array}$ & + \\
\hline Abebe 2014 & Ethiopia & Agriculture & $\begin{array}{l}\text { Combined SFA with } \\
\text { instrumental variable }\end{array}$ & + \\
\hline Chavas et al. 2005 & Gambia & Agriculture & Combined DEA with Tobit & $\begin{array}{l}\text { No systematic } \\
\text { relationship }\end{array}$ \\
\hline Babatunde 2013 & Nigeria & Agriculture & $\begin{array}{l}\text { Combined SFA with } \\
\text { instrumental variable }\end{array}$ & $\begin{array}{l}\text { No systematic } \\
\text { relationship }\end{array}$ \\
\hline $\begin{array}{l}\text { Larochelle and } \\
\text { Alwang } 2013\end{array}$ & Bolivian & Potato & SFA & - \\
\hline $\begin{array}{l}\text { Goodwin and } \\
\text { Mishra } 2004\end{array}$ & USA & Agriculture & Simultaneous equation & - \\
\hline
\end{tabular}

2014). Other studies like Abebe (2014) relied on a single frontier equation for both those who participated in off-farm activities and non-participants without giving due attention for potential differences between the two groups.

Hence, unlike previous works, this paper aims to estimate the impact of participation in off-farm activities on TE of smallholder maize producers of eastern Ethiopia by combining propensity score matching with the Greene (2010) model to control for both observed and unobserved heterogeneities.

Therefore, the results of this study adds to the existing literature (e.g., Abate et al. 2016; Barrett et al. 2001; Beyene 2008; Feng et al. 2010) through identifying the factors affecting the participation in off-farm activities. As the study evaluates the impact of participation in off-farm activities on the TE of maize producers, the study indicates the relationship between off-farm and on-farm activities and indicates whether there exists trade-off or complementarity between the two incomegenerating activities. 


\section{Methods}

Econometric framework and estimation strategies

Estimation of technical efficiency

Technical efficiency (TE) refers to the ability of a decision-making unit (DMU) to produce the maximum feasible output from a given bundle of inputs (Farrell 1957; Xiaogang et al. 2005). Any deviation from this maximal output is considered as technical inefficiency (Coelli et al. 2005). TE can be measured by using either parametric or non-parametric approaches (Simar and Wilson 2015). The main difference between the two approaches is that the non-parametric approach assumes that the DMU has full control on the production process and all deviations from the frontier are associated with inefficiency. The parametric approach on the other hand distinguishes inefficiency from deviations that are caused by factors beyond the control of the DMU. Given the intrinsic variability of agricultural production due to factors like climatic change, plant pathology, and insect and pests, the assumption that all deviations from the frontier are associated with inefficiency, as assumed in the non-parametric approaches, is difficult to accept (Bauman et al. 2016). Hence, this study has adopted a parametric approach, specifically stochastic frontier analysis (SFA). Studies that utilized SFA to measure TE include Binam et al. 2004; Balcombe et al. 2007; Bozoğlu and Ceyhan 2007; Gedara et al. 2012; and Xu et al. 2015. The stochastic production frontier (SPF) function was independently proposed by Aigner et al. 1977 and Meeusen and Von den Broeck 1977). This model can be expressed in the following form.

$$
Y_{i}=F\left(X_{i} ; \beta\right) \exp \left(V_{i}-U_{i}\right) \quad I=1,2,3 \ldots n
$$

where $Y_{i}$ is the observed maize production of the $i$ th farmer, $X_{i}$ is a vector of inputs used by the $i$ th farmer, $\beta$ is a vector of unknown parameters, $V_{i}$ is the stochastic effect beyond the farmer's control, measurement errors, and other statistical noises which are assumed to be $N\left(0, \sigma_{v}^{2}\right)$ and independent of the $U_{i}$ which is a non-negative random variable assumed to account for technical inefficiency in production. As SFA requires prior specification of functional form of the production function, a log-likelihood ratio (LR) test was conducted to choose between the Cobb-Douglas and translog functional forms using the following formula given by (Coelli 1998).

$$
L R=-2 \times\left(\ln L_{T L}-\left(\ln L_{C B}\right)\right)
$$

where $\ln L_{T L}$ and $\ln L_{C B}$ represent the $\log$-likelihood function values obtained from the translog and the Cobb-Douglas production function, respectively. The $\mathrm{LR}^{1}$ test result indicated that Cobb-Douglas production function is a more appropriate functional form for this study than the alternative translog production function. Several studies have utilized Cobb-Douglas production including Bozoğlu and Ceyhan 2007; Pfeiffer et al. 2009, and González-Flores et al. 2014.

\section{Impact evaluation and efficiency estimation}

Following the works of González-Flores et al. (2014) and Bravo-Ureta et al. (2012), we measured the impact of participating in off-farm activities on TE by combining propensity score matching (PSM) technique with the Greene (2010) model to correct biases from observed characteristics and for selectivity bias arising from unobserved variables, respectively. The first step in PSM is to predict the propensity score which 
is equal to the probability of receiving treatment, considering both treated and nontreated groups based on a given set of predetermined covariates, using a binary choice model (Cameron and Trivedi 2005). This step is followed by imposing the common support region, which is the area within the minimum and maximum propensity scores of treated and comparison groups, respectively (Caliendo and Kopeinig 2008). Several recent studies have applied PSM within the impact evaluation literature (e.g., Becerril and Abdulai 2010; Mishra et al. 2016; Abate et al. 2016; Chagwiza et al. 2016).

Nevertheless, PSM works only if selection is solely based on observable characteristics and potential outcomes are independent of treatment assignment. If unobservable characteristics affect the outcome variable, PSM is not the appropriate technique (Takahashi and Barrett 2013; Khonje et al. 2015). Hence, to handle biases from the unobserved characteristics, we used the model introduced by Greene (2010). According to this model, the sample selection and SPF models, along with their error structures, can be expressed as follows:
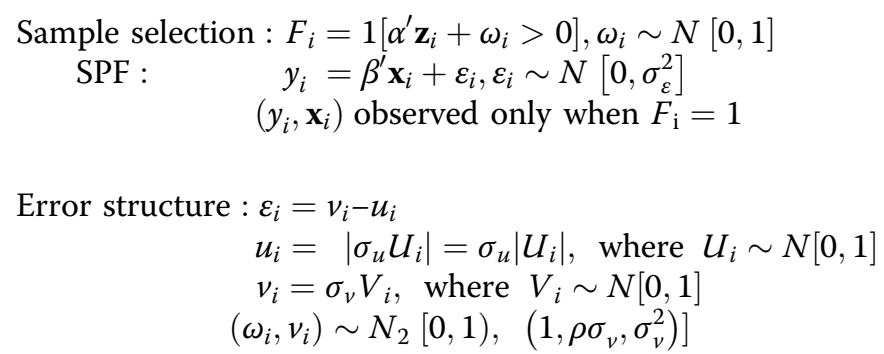

where $F$ is a binary variable equal to one for participants on off-farm activities and zero for control, $y$ is amount of maize produced, $\mathbf{z}$ is a vector of covariates included in the sample selection equation, and $\mathbf{x}$ is a vector of inputs in the production frontier; $\alpha$ and $\beta$ are parameters to be estimated while $\varepsilon_{i}$ denotes the characters in the error structure corresponding to the typical characterization of a stochastic frontier model and $\rho$ captures the presence or absence of selectivity bias.

\section{Study areas and sampling technique}

This study is undertaken in the eastern part of Ethiopia specifically in the East Hararghe Zone of Oromia National Regional State. The Zone is classified into three major climatic categories namely, temperate tropical highlands, semi-temperate, and semi-arid. This wide range of agroecology allowed the area to produce different types of products including cereals, pulses, oilseed, vegetables, fruits, and cash crops such as coffee and chat. Among the cereal crops, maize is the dominant crop as both the size of land allocated to it and the number of households producing it was the highest compared to the other cereal crops cultivated in the zone (CSA 2014). From the selected zone, two districts namely Haramaya and Girawa were selected for this study based on their extent of maize production. Next, four rural kebeles ${ }^{2}$ were randomly picked from both districts. Finally, 355 households (76 (which is equivalent to $21.41 \%$ ) participants and 279 non-participants) were selected, proportional to the size of maize-producing farmers using simple random sampling technique with replacement. ${ }^{3}$ Then, the primary data were collected using structured questionnaires administered by trained enumerators from February to March 2016. 


\section{Results and discussions}

\section{Descriptive statistics}

Before embarking to the econometrics results, it is important to give brief information regarding the sample respondents and variables used in the econometrics model. Accordingly, Table 2 presents descriptive statistics of the variables ${ }^{4}$ used for this study. As it is indicated in the table, $21 \%$ of the respondents have been participating in off-farm income-generating activities, which include selling firewood, renting assets, trading, and remittance. The mean age of the sample respondents is about 38 years. Nearly $90 \%$ of the sample households are headed by male. Concerning their educational status, $63.1 \%$ of the respondents and $24.2 \%$ of the spouses are literate. The mean family size of the respondents measured by adult equivalent $(\mathrm{AE})^{5}$ is 5.36. As far as the asset ownership is concerned, on average, they have 2.79 quxi $^{6}$ of land and 3.01 units of livestock measured by tropical livestock units (TLUs). The sample respondents, on average, travel about $35 \mathrm{~min}$ to reach the nearest market, and about $22 \%$ of respondents are members of agricultural cooperatives. The $t$ test indicated that there is a statistical mean difference between off-farm participant and non-participant households in terms of educational status of the household head and the spouse, sex of the household head, and agricultural cooperative membership. Table 2 also indicated the input and output variables used to estimate the stochastic frontier production functions.

Table 2 Descriptive statistics

\begin{tabular}{|c|c|c|c|c|c|c|}
\hline \multirow[t]{2}{*}{ Variable } & \multicolumn{2}{|c|}{ Pooled $(n=355)$} & \multicolumn{2}{|c|}{ Participants $(n=76)$} & \multicolumn{2}{|c|}{ Non-participants $(n=279)$} \\
\hline & Mean & Std. dev. & Mean & Std. dev. & Mean & Std. dev. \\
\hline District & 1.437 & 0.497 & 1.487 & 0.503 & 1.423 & 0.495 \\
\hline Off_farm & 0.214 & 0.411 & 1.00 & 0.00 & - & - \\
\hline Education_HH & $0.631^{*}$ & 0.483 & 0.724 & 0.450 & 0.606 & 0.490 \\
\hline Education_spouse & $0.242^{* *}$ & 0.429 & 0.368 & 0.486 & 0.208 & 0.407 \\
\hline Age_HH & 37.930 & 8.804 & 37.579 & 8.341 & 38.025 & 8.938 \\
\hline Sex_HH & $0.896^{*}$ & 0.306 & 0.829 & 0.379 & 0.914 & 0.281 \\
\hline Coop & $0.217^{* * *}$ & 0.413 & 0.382 & 0.489 & 0.172 & 0.378 \\
\hline Land owned & 2.786 & 2.228 & 2.938 & 1.902 & 2.744 & 2.311 \\
\hline Distance_mkt & 34.640 & 21.716 & 33.355 & 20.864 & 34.990 & 21.966 \\
\hline Social_role & 0.31 & 0.463 & 0.368 & 0.486 & 0.294 & 0.456 \\
\hline Market_info & $0.487^{* * *}$ & 0.027 & 0.711 & 0.052 & 0.427 & 0.03 \\
\hline Livestock & 3.010 & 1.871 & 2.987 & 2.017 & 3.017 & 1.833 \\
\hline Family AE & 5.361 & 1.802 & 5.586 & 1.940 & 5.300 & 1.762 \\
\hline Value_yield & $5467.268^{* * *}$ & 3886.116 & 7091.053 & 4380.921 & 5024.946 & 3624.290 \\
\hline Value_fertilizer & $468.069^{* *}$ & 434.974 & 590.155 & 524.878 & 434.812 & 401.768 \\
\hline Value_seed & $164.193^{* * *}$ & 116.374 & 207.586 & 133.923 & 152.373 & 108.404 \\
\hline Value_labor & $1793.965^{* * * *}$ & 1091.748 & 2266.322 & 1163.708 & 1665.295 & 1036.727 \\
\hline Land_maize & $2.066^{* * *}$ & 1.447 & 2.618 & 1.697 & 1.916 & 1.335 \\
\hline
\end{tabular}




\section{Econometrics results}

\section{Determinants of participation in off-farm activities}

This sub-section presents the result of the probit regression model, which was used to estimate the propensity score for matching the off-farm participants with nonparticipants. The model sufficiently fitted the data at one significant level (LR $\chi^{2}(12)=$ 42.34; Prob $\left.>\chi^{2}=0.00\right)$. The result, presented in Table 3, reveals that sex of the household head, literacy of the spouse, agricultural cooperative membership, family size, and access to market information have significant effect on farmers' participation in offfarm activities. Specifically, the result implies that being a female-headed household increases the probability of participation in off-farm activities.

Female-headed households are more likely to participate in off-farm activities than the male-headed counterparts because female-headed families engage in off-farm activities to offset their relative lower farm income compared to male-headed ones. However, this is against the result found by Beyene (2008).

Literacy of the spouse influences the participation in off-farm activities positively. Educated people have lower incentive to obtain income from own farming because educated people often have access to higher paying off-farm jobs (Lanjouw 2001; Satriawan and Swinton 2007) compared to uneducated ones. Therefore, the educated spouse would engage in higher earning off-farm activities so as to improve the livelihood of their family.

Agricultural cooperative membership has a positive influence on farmers' participation in off-farm activities. When a farmer becomes a cooperative member, he/she can get relatively more information from his/her fellows about the available off-farm works compared to non-members. Hence, his/her participation in off-farm activities would be more likely than the non-members.

Family size measured in terms of adult equivalent is an indicator of labor availability, and it has a positive influence to participate in off-farm activities. This is consistent with the results by Tassew et al. (2000) in such a way that large family size increases the households' participation in off-farm works since a larger family size requires

Table 3 Result of the Probit model of factors determining participation in off-farm activities

\begin{tabular}{lll}
\hline Off_farm & Coef. & Std. err. \\
\hline Education_HH & 0.055 & 0.295 \\
Education_spouse & $0.580^{*}$ & 0.326 \\
District & 0.208 & 0.342 \\
Age_HH & -0.014 & 0.018 \\
Sex_HH & $-0.740^{*}$ & 0.424 \\
coop & $1.032^{* * *}$ & 0.327 \\
Social_role & -0.318 & 0.336 \\
Landowned & 0.003 & 0.061 \\
Market_info & $1.098^{* * *}$ & 0.301 \\
Distance_mkt & -0.001 & 0.007 \\
Livestock & -0.120 & 0.089 \\
Family AE & $0.192^{* *}$ & 0.093 \\
Cons & $-2.084^{* *}$ & 0.836 \\
\hline
\end{tabular}

*Significance at $10 \%$ level

**Significance at 5\% level

***Significance at $1 \%$ level 
relatively higher marginal income. This means that participation in off-farm activities can maintain the burden of large family size. Thus, households with large family size would have abundant labor and send some of the family members to off-farm activities.

Access to market information has a positive influence on farmers' participation in off-farm activities. Access to information about the availability of high-earning off-farm activities would give an opportunity to participate in those activities.

After estimating the probit model, we predicted the propensity scores and the common support region. The values of propensity scores of both treatment and comparison groups are found between 0.04806759 and 0.71167307 . This leads to the total matched sample size of 344 respondents of whom 76 are participants and 268 are nonparticipants. Figure 1 shows the density estimates of the distribution of propensity scores for each group, along with the areas with and without common support.

\section{Estimation of the SPF and measuring technical efficiency}

Once the matched samples are constructed, the next step is to determine if the conventional SPF should be run for the whole sample or if separate frontiers are necessary for participant and non-participant farmers. To determine this, we conducted a LR test based on following specification:

$$
L R=-2 \times\left(\ln L_{P}-\left(\ln L_{d}+\ln L_{C}\right)\right)
$$

where $\ln L_{B} \ln L_{d}$, and $\ln L_{C}$ represent the $\log$-likelihood function values obtained from the pooled model, the participant, and the non-participant subsamples, respectively. Hence, we first estimated a SPF with pooled data by including a binary variable, Off farm, as a regressor, which indicates whether the household participates or not in off-farm activities, and two separate SPF models, one for households participating in off-farm activities and the other for non- participants. The pooled SPF models indicated that there is no significant difference between the two groups of farmers in their TE score as the variable Off_farm are insignificant under both matched and unmatched SPF. However, this result is rejected by the LR test, which favors separate frontiers indicating the two groups have different production function. Then, to correct for the possible bias from observable heterogeneities, we re-estimated the above three frontiers (pooled, participants, and nonparticipants) using the matched data set. ${ }^{7}$ However, results of LR test again supported separate frontiers for each groups. Finally, to correct for the possible bias from unobservables, two separate SPF models are re-estimated using Greene's (2010) selection

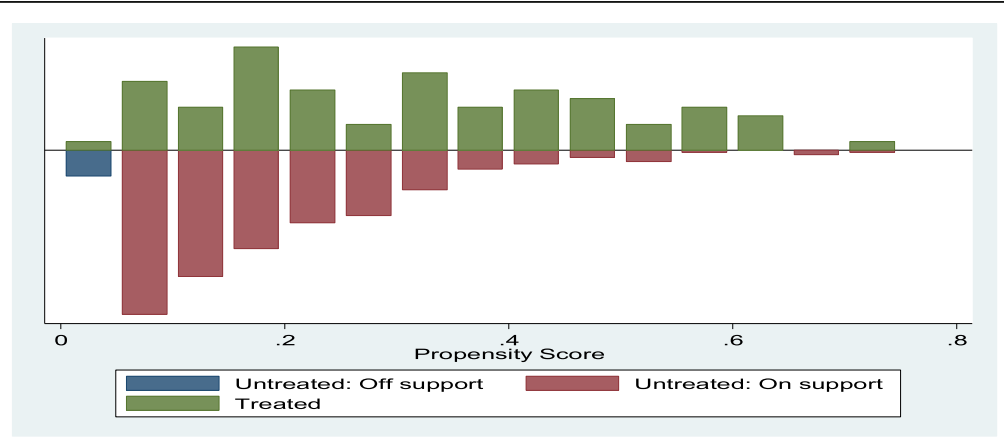

Fig. 1 The distribution of propensity scores for treated and untreated groups 
Table 4 Conventional and selection SPF based on unmatched observation

\begin{tabular}{|c|c|c|c|c|c|c|c|c|c|c|}
\hline & \multicolumn{6}{|c|}{ Conventional SPF } & \multicolumn{4}{|l|}{ Selection } \\
\hline & \multicolumn{2}{|l|}{ Pooled } & \multicolumn{2}{|c|}{ Participant } & \multicolumn{2}{|c|}{ Non-participant } & \multicolumn{2}{|l|}{ Participant } & \multicolumn{2}{|c|}{ Non-participant } \\
\hline & Coef & se & Coef & se & Coef & se & Coef & se & Coef & se \\
\hline Cons & $5.568^{* * *}$ & 0.756 & $5.011^{* * *}$ & 0.000 & $5.615^{* * *}$ & 0.917 & $5.92418^{* * *}$ & 0.4524 & $4.96669^{* * *}$ & 0.667 \\
\hline Value_fertilizer & $0.003^{* * *}$ & 0.001 & $0.003^{* * *}$ & 0.000 & $0.003^{* * *}$ & 0.001 & $.00267^{* * *}$ & 0.0003 & $.00406^{* * *}$ & 0.001 \\
\hline Value_seed & $0.558^{* * *}$ & 0.173 & $0.579^{* * *}$ & 0.000 & $0.572^{* * *}$ & 0.212 & $.40810^{* * *}$ & 0.0964 & $.72837^{* * *}$ & 0.152 \\
\hline Value_labor & 0.012 & 0.023 & $0.076^{* * *}$ & 0.000 & -0.003 & 0.030 & $.05214^{* * *}$ & 0.0098 & -0.00711 & 0.029 \\
\hline Land_maize & $0.410^{* *}$ & 0.174 & $0.315^{* * *}$ & 0.000 & $0.415^{*}$ & 0.212 & $.49672^{* * *}$ & 0.1002 & $.25527^{*}$ & 0.152 \\
\hline Off_farm & -0.002 & 0.015 & & & & & & & & \\
\hline Sigma & $0.091^{* * *}$ & 0.007 & $0.033^{* * *}$ & 0.005 & $0.106^{* * *}$ & 0.010 & & & & \\
\hline Sigma(u) & & & & & & & $.21502^{* * *}$ & 0.0033 & $.42371^{* * *}$ & 0.014 \\
\hline Sigma(v) & & & & & & & $.01373^{* *}$ & 0.0059 & $.04182^{* * *}$ & 0.012 \\
\hline $\operatorname{Rho}(w, v)$ & & & & & & & $.96882^{* * *}$ & 0.0905 & -0.40401 & 1.579 \\
\hline
\end{tabular}

*Significance at $10 \%$ level

** Significance at $5 \%$ level

***Significance at $1 \%$ level

correction framework. The results of the SPF models are presented in Table 4 for the unmatched samples and in Table 5 for the matched samples.

The estimated value of sigma are significant at less than $1 \%$ probability level for all frontier functions indicating the conventional average production function is not an adequate representation of the data. The coefficients of rho, which indicate the presence of selection bias, are also significant in all selection frontiers except for the nonparticipants in the case of the unmatched data. This result suggests the presence of selection bias, thus lending support to the use of a sample selection framework to estimate separate SPFs for the beneficiaries and control groups.

As it is presented in the tables, the signs of all significant variables are positive as we expected. However, different input-output responses are found between these two groups of farmers. The result indicates that expenditure on inorganic fertilizer and seed are significant in all frontiers, while labor is found to be insignificant for nonparticipant respondents, which indicate that the amount of labor has no impact in

Table 5 Conventional and selection SPF based on matched observations

\begin{tabular}{|c|c|c|c|c|c|c|c|c|c|c|}
\hline & \multicolumn{6}{|c|}{ Conventional SPF } & \multicolumn{4}{|l|}{ Selection } \\
\hline & \multicolumn{2}{|l|}{ Pooled } & \multicolumn{2}{|c|}{ Participant } & \multicolumn{2}{|c|}{ Non-participant } & \multicolumn{2}{|l|}{ Participant } & \multicolumn{2}{|c|}{ Non-participant } \\
\hline & Coef & se & Coef & se & Coef & se & Coef & se & Coef & se \\
\hline cons & $4.407^{* * *}$ & 1.173 & $5.011^{* * *}$ & 0.000 & $3.459^{* *}$ & 1.753 & $3.30277^{* * *}$ & 0.41786 & $4.59917^{* * *}$ & 1.44511 \\
\hline Value_fertilizer & $0.003^{* * *}$ & 0.001 & $0.003^{* * *}$ & 0.000 & $0.003^{* * *}$ & 0.001 & $.00466^{* * *}$ & 0.00033 & $.00391^{* * *}$ & 0.00058 \\
\hline Value_seed & $0.839^{* * *}$ & 0.275 & $0.579^{* * *}$ & 0.000 & $1.092^{* * *}$ & 0.414 & $1.00655^{* * *}$ & 0.09091 & $.78095^{* *}$ & 0.33539 \\
\hline Value_labor & 0.002 & 0.023 & $0.076^{* * *}$ & 0.000 & -0.020 & 0.028 & $.05404^{* * *}$ & 0.01047 & 0.01089 & 0.02271 \\
\hline Land_maize & 0.131 & 0.273 & $0.315^{* * *}$ & 0.000 & -0.104 & 0.411 & -0.08678 & 0.09178 & 0.17441 & 0.34022 \\
\hline Off_farm & 0.002 & 0.015 & & & & & .00169 & .015266 & & \\
\hline Sigma & $.29978^{* * *}$ & 0.001 & $0.033^{* * *}$ & 0.005 & $0.105^{* * *}$ & 0.010 & & & & \\
\hline $\operatorname{Sigma}(u)$ & & & & & & & $.18861^{* * *}$ & 0.0029 & $.35989^{* * *}$ & 0.0098 \\
\hline Sigma(v) & & & & & & & $.00973^{* *}$ & 0.00449 & $.04921^{* * * *}$ & 0.0093 \\
\hline $\operatorname{Rho}(w, v)$ & & & & & & & $.76645^{* *}$ & 0.39002 & $.89504^{* * *}$ & 0.33496 \\
\hline
\end{tabular}

*Significance at $10 \%$ level

**Significance at $5 \%$ level

*** Significance at $1 \%$ level 


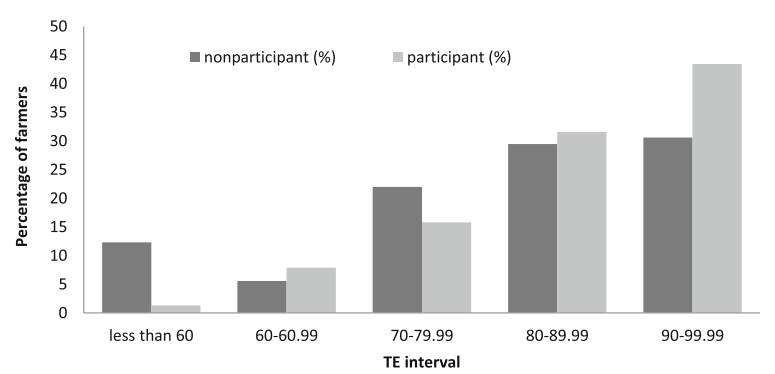

Fig. 2 The distribution of TE score for participant and non-participant farmers

determining the production level of maize in this subsample. Almost in all frontiers, the average production elasticity of seed and land allocated for maize are the highest.

\section{Impact of participation in off-farm activities on technical efficiency}

After estimating the SPF corrected for both observed and unobserved heterogeneities, we predicted the TE score of each sample respondent. Figure 2 presents the distribution of TE score for both participant and non-participant farmers. The TE scores range between 39.27 and 99.56 for the entire population. It indicates that the TE scores of $37.21 \%$ percent of the maize producers considered for this study were below the mean efficiency level. Considering only the participants, the TE score is ranged between 59.39 and 99.56 and the corresponding figure for the nonparticipants is found between 39.27 and 99.06 .

Table 6 summarizes the TE mean difference between the two groups after correcting for bias from both observable and non-observable heterogeneities. The results indicate a significant mean difference between the two groups. Specifically, the result reveals farmers who are participating in off-farm income-generating activities have $6.23 \%$ of technical efficiency gain compared with their non-participant counterparts. The result is consistent with Pfeiffer et al. (2009).

As indicated in Table 5, the mean TE for pooled sample respondents was found to be 81.44\% and the corresponding figure for households participating in off-farm activities and non-participants are 86.29 and $80.06 \%$, respectively.

Finally, we examined which of the two groups (participants vs. nonparticipants) has higher output after controlling for biases from observed and unobserved variables. For this purpose, we compared the predicted frontier output of the two groups at three different input levels: (1) at the average for the smallest matched pair of farms, (2) at the average for the entire sample, and (3) at the average for the largest matched pair. The result is indicated along with a test of the mean difference in Table 7. As it is indicated in the table, households who are participating in off-farm activities are significantly more productive than the non-participant farmers. Thus, the analysis suggests that participants do not only exhibit higher TE but also higher total output.

Table 6 TE scores after bias correction

\begin{tabular}{|c|c|c|c|c|c|c|c|}
\hline \multirow[t]{2}{*}{ Variable } & \multicolumn{2}{|c|}{ Combined } & \multicolumn{2}{|c|}{ Participants } & \multicolumn{2}{|c|}{ Non-participants } & \multirow{2}{*}{$\begin{array}{l}\text { Difference } \\
\text { Mean }\end{array}$} \\
\hline & Mean & Std. err. & Mean & Std. err. & Mean & Std. err. & \\
\hline TE & 81.44 & 0.008 & 86.29 & 0.012 & $80.06 \%$ & 0.009 & $6.23 \% * * *$ \\
\hline
\end{tabular}


Table 7 Predicted frontier output after bias correction

\begin{tabular}{llllc}
\hline Predict frontier & Mean & Min & Max & Significance level \\
\hline Participants & 8225.957 & 2844.444 & $25,848.23$ & $* * *$ \\
Non-participants & 6187.10 & 2775.337 & $20,651.33$ & \\
\hline
\end{tabular}

*** significant at $1 \%$ probability level

\section{Conclusion}

This study analyzed the determinants of participation in off-farm activities and examined the impact of participation in off-farm activities on technical efficiency of maize production in eastern Ethiopia using data collected from 355 households. The probit model results indicate that literacy of the spouse, agricultural cooperative membership, family size, and access to market information had positively and significantly affected the participation in off-farm activities whereas male household head had negative and significant effect on participation in off-farm activities. The stochastic frontier production function was used to estimate technical efficiency scores, and propensity score matching was combined with Green (2010) to control sample selection bias. The result indicated that participation in off-farm activities have a positive influence on both production and productivity of maize. The result suggests that participants in off-farm activities are more technically efficient in maize production than the non-participants. The finding of this study indicated the existence of complementarity between on-farm and off-farm activities. This result challenges the perception that participation in off-farm activities may lead to a reduction in on-farm production due to competition between farm and off-farm works for family labor. The result indicates that livelihood diversification improves the agriculture sector in addition to creation of more employment opportunities as it provides a medium for family labor reallocation. This confirms the fact that off-farm income enhances agricultural production and productivity by providing cash to purchase agricultural technologies and efficiently utilize those resources.

Hence, given the complementarities between off-farm and farm activities, providing services like education and market information to the farmers and strengthening agricultural cooperatives should be facilitated to increase the participation of farmers in off-farm activities and in turn to improve their livelihoods.

\section{Endnotes}

${ }^{1}$ The critical value for a test of size $\alpha$ is equal to the value $\chi^{2}(\alpha)$, where this is the value, which is exceeded by the $\chi_{1}^{2}$ random variable with probability equal to $2 \alpha$ (Coelli 1998).

${ }^{2}$ Kebele is the smallest administrative hierarchy in Ethiopia.

${ }^{3}$ Every kebele administration has a full list of households living in the area. We used this list as a sample frame. When the randomly selected farmer does not produce maize he/she will be replaced by a farmer next to him/her in the list.

${ }^{4}$ List and definition of variables used for this study is presented under Table 8 in the Appendix.

${ }^{5}$ Family size is calculated by converting difference in age and sex of members of the family members using conversion factor given in Table 9, and Table 10 in the Appendix indicates the conversion factor used to compute TLU.

${ }^{6}$ quxi is a local measurement unit equivalent with $1 / 8$ of a hectare

${ }^{7}$ The sensitivity analysis is presented under Table 11 in the Appendix. 


\section{Appendix}

Table 8 Definition of variables

\begin{tabular}{|c|c|c|}
\hline Variable & Unit & Definition \\
\hline District & Dummy & 1 if the household is living in Girawa district; 0 otherwise. \\
\hline Off_farm & Dummy & 1 if the household participates in off-farm activities; 0 otherwise. \\
\hline Education_HH & Dummy & 1 if the household head is literate; 0 otherwise. \\
\hline Education_spouse & Dummy & 1 if the spouse of household head is literate; 0 otherwise. \\
\hline Age_HH & Years & Number of years the household head lived \\
\hline Sex_HH & Dummy & 1 if the household head is male; 0 otherwise. \\
\hline Coop & Dummy & 1 if the household is a member of agricultural cooperatives; 0 otherwise. \\
\hline Landowned & quxi & Size of land owned by the household \\
\hline Distance_mkt & Minute & Distance between the nearest market \\
\hline Social_role & Dummy & 1 if the household head has social responsibility; 0 otherwise \\
\hline Market_info & Dummy & 1 if the household head has access to market information; 0 otherwise \\
\hline Livestock & TLU & Size of livestock owned by the household \\
\hline FamlyAE & $\mathrm{AE}$ & Family size measured by adult equivalent \\
\hline Value_yield & Birr $^{1}$ & Value of maize produced by the household \\
\hline Value_fertilizer & Birr & Value of inorganic fertilizer utilized for maize production \\
\hline Value_seed & Birr & Value of seed used for maize production \\
\hline Value_labor & Birr & Value of hired and family labor used for maize production \\
\hline Land_maize & quxi & Size of land allocated for maize production \\
\hline
\end{tabular}

${ }^{1}$ Ethiopian currency; 1USD was equivalent with 21.21 ETB in the time of data collection

Table 9 Conversion factor for computation of adult equivalent

\begin{tabular}{lll}
\hline & Adult equivalent & \\
\hline Age group (years) & Male & Female \\
$<10$ & 0.6 & 0.6 \\
$11-13$ & 0.9 & 0.8 \\
$14-16$ & 1 & 0.75 \\
$17-50$ & 1 & 0.75 \\
$>50$ & 1 & 0.7 \\
\hline
\end{tabular}

Source: Storck et al. (1991)

Table 10 Conversion factors used to estimate tropical livestock unit (TLU) equivalents

\begin{tabular}{lc}
\hline Animal category & TLU \\
\hline Calf & 0.25 \\
Donkey (young) & 0.35 \\
Weaned calf & 0.34 \\
Camel & 1.25 \\
Heifer & 0.75 \\
Sheep and goat (adult) & 0.13 \\
Cow and ox & 1.00 \\
Sheep and goat (young) & 0.06 \\
Horse & 1.10 \\
Chicken & 0.013 \\
Donkey (adult) & 0.70 \\
\hline
\end{tabular}

Source: Storck, et al. (1991) 
Table 11 Sensitivity analyses

\begin{tabular}{lllllll}
\hline Gamma & sig+ & sig- & t-hat + & t-hat - & $\mathrm{Cl}+$ & $\mathrm{Cl}-$ \\
\hline 1 & 0 & 0 & 0.837 & 0.837 & 0.823 & 0.847 \\
1.25 & 0 & 0 & 0.822 & 0.847 & 0.81 & 0.867 \\
1.5 & 0 & 0 & 0.812 & 0.865 & 0.793 & 0.881 \\
1.75 & 0 & 0 & 0.798 & 0.877 & 0.78 & 0.891 \\
1 & 0 & 0 & 0.837 & 0.837 & 0.823 & 0.847 \\
\hline
\end{tabular}

Gamma log odds of differential assignment due to unobserved factors, sig + upper bound significance level, sig- lower bound significance level, $t$-hat + upper bound Hodges-Lehmann point estimate, $t$-hat- lower bound Hodges-Lehmann point estimate, $\mathrm{Cl}+$ upper bound confidence interval $(a=.95), \mathrm{Cl}$ - lower bound confidence interval $(a=.95)$

\section{Abbreviations}

CSA: Central Statistical Agency; DEA: Data envelopment analysis; DMU: Decision-making unit; PSM: Propensity score matching; SFA: Stochastic production approach; SPF: Stochastic production frontier; TE: Technical efficiency

\section{Acknowledgements}

We are grateful to the Haramaya University for funding this research work. We also acknowledge enumerators, sample respondents, and extension staff of the Ministry of Agriculture for their efforts that led to the success of this study.

\section{Funding}

Haramaya University financially and logistically supported this research.

\section{Availability of data and materials}

The data that support the findings of this study can be obtained from the authors based on request.

\section{Authors' contributions}

MHA conceptualized the study and designed and performed the data analysis. KAM was responsible for the design of the questionnaire, interpretation of model results, and write-up of the manuscript. Both authors read and approved the final manuscript.

\section{Authors' information}

Mr. Musa Hasen Ahmed is a staff member of the Department of Agricultural Economics at Haramaya University. He has published articles related to productivity analysis, impact evaluation, natural resource valuation, and adoption of agricultural technologies. Mr. Kumilachew Alamerie Melesse is an assistant professor of Agricultural Economics at Haramaya University. He has experience in research related to agricultural technology adoption, productivity analysis, impact evaluation, risk analysis, and agricultural market analysis.

\section{Ethics approval and consent to participate}

Ethical approval and consent to participate is not applicable for our study.

\section{Competing interests}

The authors declare that they have no competing interests.

\section{Publisher's Note}

Springer Nature remains neutral with regard to jurisdictional claims in published maps and institutional affiliations.

Received: 3 March 2017 Accepted: 20 January 2018

Published online: 09 February 2018

\section{References}

Abate GT, Rashid S, Borzaga C, Getnet K (2016) Rural finance and agricultural technology adoption in Ethiopia: does the institutional design of lending organizations matter? World Dev 84:235-253

Abebe G. G. (2014). Off-farm income and technical efficiency of smallholder farmers in Ethiopia—a stochastic frontier analysis. European Erasmus Mundus Master Program: Agricultural Food and Environmental Policy Analysis (AFEPA). Degree thesis No 862 ISSN 1401-4084, Uppsala 2014

Aigner D, Lovell CK, Schmidt P (1977) Formulation and estimation of stochastic frontier production function models. J Econ 6(1):21-37

Alasia A, Weersink A, Bollman RD, Cranfield J (2009) Off-farm labour decision of Canadian farm operators: urbanization effects and rural labour market linkages. J Rural Stud 25(1):12-24

Alemu D, Gabre-Madhin E, Dejene S (2006) From farmer to market and market to farmer: characterizing smallholder commercialization in Ethiopia. International Food Policy Research Institute, Washington, DC

Anley Y, Bogale A, Haile-Gabriel A (2007) Adoption decision and use intensity of soil and water conservation measures by smallholder subsistence farmers in Dedo district, Western Ethiopia. Land Degrad Dev 18(3):289-302

Anríquez G, Daidone S (2010) Linkages between the farm and nonfarm sectors at the household level in rural Ghana: a consistent stochastic distance function approach. Agric Econ 41(1):51-66 
Babatunde RO (2013) On-farm and off-farm works: complement or substitute. In: Evidence from Rural Nigeria. Contributed paper for the 4th International Conference of the African Association of Agricultural Economists

Babatunde RO, Qaim M (2010) Impact of off-farm income on food security and nutrition in Nigeria. Food Policy 35(4):303-311

Balcombe K, Fraser I, Rahman M, Smith L (2007) Examining the technical efficiency of rice producers in Bangladesh. J Int Dev 19(1):1-16

Barrett CB, Reardon T, Webb P (2001) Nonfarm income diversification and household livelihood strategies in rural Africa: concepts, dynamics, and policy implications. Food Policy 26(4):315-331

Bauman A, Jablonski BB, Thilmany McFadden D (2016) Evaluating scale and technical efficiency among farms and ranches with a local market orientation. In: 2016 Annual Meeting, July 31-August 2, 2016, Boston, Massachusetts (No. 236057). Agricultural and Applied Economics Association

Becerril J, Abdulai A (2010) The impact of improved maize varieties on poverty in Mexico: a propensity score-matching approach. World Dev 38(7):1024-1035

Beyene AD (2008) Determinants of off-farm participation decision of farm households in Ethiopia. Agrekon 47(1):140-161

Bezu S, Barrett CB, Holden ST (2012) Does the nonfarm economy offer pathways for upward mobility? Evidence from a panel data study in Ethiopia. World Dev 40(8):1634-1646

Bezu S, Holden S (2014) Are rural youth in Ethiopia abandoning agriculture? World Dev 64:259-272

Binam JN, Tonye J, Nyambi G, Akoa M (2004) Factors affecting the technical efficiency among smallholder farmers in the slash and burn agriculture zone of Cameroon. Food Policy 29(5):531-545

Bojnec Š, Fertő I (2013) Farm income sources, farm size and farm technical efficiency in Slovenia. Post-Communist Econ 25(3):343-356

Bozoğlu M, Ceyhan V (2007) Measuring the technical efficiency and exploring the inefficiency determinants of vegetable farms in Samsun province, Turkey. Agric Syst 94(3):649-656

Bravo-Ureta BE, Greene W, Solís D (2012) Technical efficiency analysis correcting for biases from observed and unobserved variables: an application to a natural resource management project. Empir Econ 43(1):55-72

Caliendo M, Kopeinig S (2008) Some practical guidance for the implementation of propensity score matching. J Econ Surv 22(1):31-72

Cameron AC, Trivedi PK (2005) Microeconometrics: methods and applications. Cambridge university press

Chagwiza C, Muradian R, Ruben R (2016) Cooperative membership and dairy performance among smallholders in Ethiopia. Food Policy 59:165-173

Chang HH, Wen Fl (2011) Off-farm work, technical efficiency, and rice production risk in Taiwan. Agric Econ 42(2):269-278

Chavas JP, Petrie R, Roth M (2005) Farm household production efficiency: evidence from the Gambia. Am J Agric Econ $87(1): 160-179$

Coelli T (1998) A multi-stage methodology for the solution of orientated DEA models. Oper Res Lett 23(3):143-149

Coelli TJ, Rao DSP, O'Donnell CJ, Battese GE (2005) An introduction to efficiency and productivity analysis. Springer Science \& Business Media

Collier P, Dercon S (2014) African agriculture in 50 years: smallholders in a rapidly changing world? World Dev 63:92-101

CSA (Central Statistical Agency) (2014) Report on area and production of major crops (Private Peasant Holdings, Meher Season): agricultural sample survey 2015/2016 (2008 E.C.), vol I, Addis Ababa

Davis B, Winters P, Carletto G, Covarrubias K, Quinones EJ, Zezza A, Stamoulis K, Azzarri C, Digiuseppe S (2010) A crosscountry comparison of rural income generating activities. World Dev 38(1):48-63

Dawson N, Martin A, Sikor T (2016) Green revolution in sub-saharan Africa: implications of imposed innovation for the wellbeing of rural smallholders. World Dev 78:204-218

De Janvry A, Sadoulet E (2001) Income strategies among rural households in Mexico: the role of off-farm income. World Dev 29(3):467-480

Dercon S, Hoddinott J, Woldehanna T (2012) Growth and chronic poverty: evidence from rural communities in Ethiopia. J Dev Stud 48(2):238-253

Dethier JJ, Effenberger A (2012) Agriculture and development: a brief review of the literature. Econ Syst 36(2):175-205

Diao X, Hazell P, Thurlow J (2010) The role of agriculture in African development. World Dev 38(10):1375-1383

El-Osta, H. S., Mishra, A. K., \& Morehart, M. J. (2008). Off-farm labor participation decisions of married farm couples and the role of government payments. Review of Agricultural Economics, 30(2), 311-332.

Farrell MJ (1957) The measurement of productive efficiency. Journal of the Royal Statistical Society Series A (General) 120(3):253-290

Feng S, Heerink N, Ruben R, Qu F (2010) Land rental market, off-farm employment and agricultural production in Southeast China: a plot-level case study. China Econ Rev 21(4):598-606

Foster AD, Rosenzweig MR (2004) Agricultural productivity growth, rural economic diversity, and economic reforms: India, 1970-2000. Econ Dev Cult Chang 52(3):509-542

Francesconi GN, Heerink N (2011) Ethiopian agricultural cooperatives in an era of global commodity exchange: does organisational form matter? J Afr Econ 20(1):153-177

Gedara KM, Wilson C, Pascoe S, Robinson T (2012) Factors affecting technical efficiency of rice farmers in village reservoir irrigation systems of Sri Lanka. J Agric Econ 63(3):627-638

González-Flores M, Bravo-Ureta BE, Solís D, Winters P (2014) The impact of high value markets on smallholder productivity in the Ecuadorean Sierra: a stochastic production frontier approach correcting for selectivity bias. Food Policy 44:237-247

Goodwin BK, Mishra AK (2004) Farming efficiency and the determinants of multiple job holding by farm operators. Am J Agric Econ 86(3):722-729

Greene W (2010) A stochastic frontier model with correction for sample selection. J Prod Anal 34(1):15-24

Haggblade S, Hazell P, Reardon T (2010) The rural non-farm economy: prospects for growth and poverty reduction. World Dev 38(10):1429-1441

Haji J (2007) Production efficiency of smallholders' vegetable-dominated mixed farming system in eastern Ethiopia: a non-parametric approach. J Afr Econ 16(1):1-27 
Headey D, Dereje M, Taffesse AS (2014) Land constraints and agricultural intensification in Ethiopia: a village-level analysis of high-potential areas. Food Policy 48:129-141

Hoang TX, Pham CS, Ulubaşoğlu MA (2014) Non-farm activity, household expenditure, and poverty reduction in rural Vietnam: 2002-2008. World Dev 64:554-568

Kassie M, Jaleta M, Shiferaw B, Mmbando F, Mekuria M (2013) Adoption of interrelated sustainable agricultural practices in smallholder systems: evidence from rural Tanzania. Technol Forecast Soc Chang 80(3):525-540

Khonje M, Manda J, Alene AD, Kassie M (2015) Analysis of adoption and impacts of improved maize varieties in eastern Zambia. World Dev 66:695-706

Kilic T, Carletto C, Miluka J, Savastano S (2009) Rural nonfarm income and its impact on agriculture: evidence from Albania. Agric Econ 40(2):139-160

Lamb RL (2003) Fertilizer use, risk, and off-farm labor markets in the semi-arid tropics of India. Am J Agric Econ 85(2):359-371

Lanjouw JO, Lanjouw P (2001) The rural non-farm sector: issues and evidence from developing countries. Agric Econ 26(1):1-23

Lanjouw P (2001) Nonfarm employment and poverty in rural El Salvador. World Dev 29(3):529-547

Lanjouw P, Murgai R (2009) Poverty decline, agricultural wages, and nonfarm employment in rural India: 1983-2004. Agric Econ 40(2):243-263

Larochelle C, Alwang J (2013) The role of risk mitigation in production efficiency: a case study of potato cultivation in the Bolivian Andes. J Agric Econ 64(2):363-381

Larsen AF, Lilleør HB (2014) Beyond the field: the impact of farmer field schools on food security and poverty alleviation. World Dev 64:843-859

Lien G, Kumbhakar SC, Hardaker JB (2010) Determinants of off-farm work and its effects on farm performance: the case of Norwegian grain farmers. Agric Econ 41(6):577-586

Matshe I, Young T (2004) Off-farm labour allocation decisions in small-scale rural households in Zimbabwe. Agric Econ 30(3):175-186

Meeusen W, van Den Broeck J (1977) Efficiency estimation from Cobb-Douglas production functions with composed error. Int Econ Rev 18:435-444

Minten B, Barrett CB (2008) Agricultural technology, productivity, and poverty in Madagascar. World Dev 36(5):797-822

Mishra AK, Kumar A, Joshi PK, D'souza A (2016) Impact of contracts in high yielding varieties seed production on profits and yield: the case of Nepal. Food Policy 62:110-121

Mishra AK, Mottaleb KA, Mohanty S (2015) Impact of off-farm income on food expenditures in rural Bangladesh: an unconditional quantile regression approach. Agric Econ 46(2):139-148

Mochebelele MT, Winter-Nelson A (2000) Migrant labor and farm technical efficiency in Lesotho. World Dev 28(1):143-153

Oseni G, Winters P (2009) Rural nonfarm activities and agricultural crop production in Nigeria. Agric Econ 40(2):189-201

Owusu V, Abdulai A, Abdul-Rahman S (2011) Non-farm work and food security among farm households in Northern Ghana. Food Policy 36(2):108-118

Pfeiffer L, López-Feldman A, Taylor JE (2009) Is off-farm income reforming the farm? Evidence from Mexico. Agric Econ 40(2):125-138

Ruben R (2001) Nonfarm employment and poverty alleviation of rural farm households in Honduras. World Dev 29(3):549-560

Satriawan E, Swinton SM (2007) Does human capital raise farm or nonfarm earning more? New insight from a rural Pakistan household panel. Agric Econ 36(3):421-428

Simar L, Wilson PW (2015) Statistical approaches for non-parametric frontier models: a guided tour. Int Stat Rev 83(1):77-110

Smith LED, Nguyen Khoa S, Lorenzen K (2005) Livelihood functions of inland fisheries: policy implications in developing countries. Water Policy 7:359-383

Stampini M, Davis B (2009) Does nonagricultural labor relax farmers' credit constraints? Evidence from longitudinal data for Vietnam. Agric Econ 40(2):177-188

Storck H, Emana B, Adnew B, Borowiccki A, Woldehawariat S (1991) Farming systems and resource economics in the tropics: farming system and farm management practices of smallholders in the Hararghe Highland, vol II. Wissenschaftsverlag Vauk, Kiel

Takahashi K, Barrett CB (2013) The system of rice intensification and its impacts on household income and child schooling: evidence from rural Indonesia. Am J Agric Econ aat086

Tassew W, Lansink AO, Peerlings J (2000) Off-farm work decisions on Dutch cash crop farms and the 1992 and agenda 2000 CAP reforms. Agric Econ 22(2000):163-171

Teshome A, de Graaff J, Kessler A (2016) Investments in land management in the north-western highlands of Ethiopia: the role of social capital. Land Use Policy 57:215-228

Tijani AA (2006) Analysis of the technical efficiency of rice farms in ljesha Land of Osun State, Nigeria. Agrekon 45(2): $126-135$

Wouterse F, Taylor JE (2008) Migration and income diversification: evidence from Burkina Faso. World Dev 36(4):625-640

Xiaogang C, Skully M, Brown K (2005) Banking efficiency in China: application of DEA to pre- and post-deregulation eras: 1993-2000. China Econ Rev 16(3):229-245

XU TIAN, SUN FF, ZHOU YH (2015) Technical efficiency and its determinants in China's hog production. J Integr Agric 14(6):1057-1068

Yang J, Wang H, Jin S, Chen K, Riedinger J, Peng C (2016) Migration, local off-farm employment, and agricultural production efficiency: evidence from China. J Prod Anal 45(3):247-259

Zezza A, Carletto G, Davis B, Stamoulis K, Winters P (2009) Rural income generating activities: whatever happened to the institutional vacuum? Evidence from Ghana, Guatemala, Nicaragua and Vietnam. World Dev 37(7):1297-1306

Zhang L, Su W, Eriksson T, Liu C (2016) How off-farm employment affects technical efficiency of China's farms: the case of Jiangsu. China \& World Economy 24(3):37-51 